\title{
Increasing The Role As Well As Communities In The Construction Of Forest Fire Through The Strengthening Of Individual Institutions In Muaro Jambi District
}

\author{
Afif Syarif, Fitria \\ Fakultas Hukum, Universitas Jambi
}

\begin{abstract}
Abstrak: Disasters of forest and land fires accompanied by smoke disasters that hit Jambi Province especially in Muaro Jambi Regency have an impact on the health, environment and economy of the people both in Indonesia and in neighboring countries, Malaysia and Singapore. This legal counseling aims to describe and analyze the strengthening of customary institutions in the prevention and control of forest and land fires in Muaro Jambi District. This legal extension uses a type of descriptive approach with a qualitative approach. The focus of this legal counseling is the strengthening of indigenous peoples' institutions in the prevention and control of forest and land fires. The expected outcome of this legal counseling is the strengthening of indigenous peoples' institutions in the prevention and control of forest and land fires that have not been effective. The advice given is in fire control should be at the stage of prevention of preventive and repressive measures in the enforcement of environmental law against forest and land burning in Muaro Jambi district.
\end{abstract}

Keywords: Forest and Land Fires; Community participation ; Customary Institution

\section{PENDAHULUAN}

Kebakaran hutan dan lahan di Provinsi Jambi hampir setiap tahun terjadi, wilayah yang kebakaran biasanya terjadi pada musim kemarau, lahan yang paling luas terbakar adalah lahan gambut, mayoritas terjadi pada areal konsensi perusahaan perkebunan kelapa sawit dan hutan tanaman industri yang berproduksi diatas lahan gambut. Walhi Jambi sendiri memastikan $80 \%$ titik api berada sebaran titik api berada di izin HTI dan sawit Akibat kebakaran hutan dan lahan tersebut, menyebabkan bencana asap dan pemanasan global. Sementara itu kemarau ekstrim yang seringkali dikaitkan dengan pengaruh iklim yang memberikan kondisi ideal untuk terjadinya kebakaran hutan dalam pengelolaan lahan.

Di Provinsi Jambi berdasarkan pantauan Satelit National Oceanic Atsmospheric Administration (NOAA) 18 sebaran titik api tersebut berada di areal masyarakat, areal hutan tanaman industri (HTI), areal perkebunan kelapa sawit, hutan lindung dan lahan gambut. Alih fungsi hutan dan pembukaan hutan dengan cara ini lebih murah dibandingkan dengan cara tidak merusak lingkungan. Selain itu, kebakaran didukung oleh pemanasan global, kemarau ekstrim yang seringkali dikaitkan dengan pengaruh iklim yang memberikan kondisi ideal untuk terjadinya kebakaran hutan.

Kabupaten Muaro Jambi merupakan salah satu kabupaten di Provinsi Jambi terjadinya kebakaran hutan dan lahan akibat alih fungsi hutan dan pembukaan areal perkebunan kelapa sawit terhadap hutan lindung dan lahan gambut yang sulit dihindari dan akan terjadinya kebakaran hutan dan kerusakan lahan. Bertitik tolak dari kasus kebakaran hutan dan lahan sebelumnya di Provinsi Jambi, menunjukan bahwa kasus kebakaran hutan dan lahan di Provinsi Jambi sudah pada status tersangka yang dikeluarkan oleh Polda Jambi dan Kapolres di beberapa kabupaten Provinsi Jambi, adapun kasus tersangka terhadap pembakaran hutan dan lahan tersebut baik perorangan maupun koorporasi dari tahun ke tahun belum dapat ditindak lanjuti secara hukum.

Berdasarkan hal tesebut perlu dilakukan penyuluhan hukum melalui pengabdian kepada masyarakat secara rutin setiap tahun akibat lemahnya penguatan kelembagaan 
masyarakat adat terhadap pencegahan dan pengendalian kebakaran hutan dan lahan. Maka tujuan penyuluhan hukum ini adalah memperkuat kelembagaan masyarakat adat dalam penanggulangan kebakaran hutan dan lahan, disamping itu masyarakat adat dapat membantu pemerintahan Kabupaten Muaro Jambi dalam penanggulangan kebakaran hutan dan lahan di kabupaten Muaro Jambi.

Beradasarkan uraian tersebut, permasalahan kebakaran hutan dann lahan di Kabupaten Muaro Jambi khususnya Kecamatan Maro Sebo dan Sungai Gelam adalah berkaitan dengan permasalahan di atas yang begitu rumit dan kompleks mengatasi kebakaran hutan dan lahan di kecamatan Maro Sebo. Apabila dianalis permasalahan tersebut, dapat dirumuskan sebagai berikut (1) Bagaimana peran serta masyarakat dalam menanggulangi kebakaran hutan dan lahan; (2) Bagaimana metode penguatan kelembagaan masyarakat adat dalam penanggulangan kebakaran hutan dan lahan di kabupaten Muaro Jambi.

\section{METODE PELAKSANAAN}

Penyuluhan hukum ini dilakukan di Kecamatan Maro Sebo dan Kecamatan Sungai Gelam kabupaten Muaro Jambi, untuk itu dilakukan koordinasi dengan pemerintah Kecamatan dengan melibatkan Kepala Desa dan Ketua Adat di Kecamatan Sungai Gelam dan Maro Sebo Kabupaten Muaro Jambi. Sedangkan pendekatan yang dgunakan dalam penyuluhan hukum kehutanan ini adalah dengan menggunakan :

1. Pendekatan normatif, yaitu melihat dan mengkaji hubungan masyarakat dengan hutan disekitar kawasan hutan berdasarkan pola-pola pemikiran tokoh-tokoh adat, kemudian melihat batas-batas kawasan hutan adat berdasarkan norma hukum yang mareka akui ;

2. Pendekatan sosiologis, yaitu melihat kerakteristik hak-hak adat masyarakat atas hutan, hal ini dilakukan melalui observasi baik melalui ketua adat, pejabat desa dan anggota masyarakat adat lainnya.

3. Pendekatan historis, yaitu melihat sejarah hutan adat berdasarkan hubungan geneologis masyarakat dengan hutan

Sementara penyuluhan hukum tentang kebakaran hutan dan lahan ini dilakukan melalui berbagai pendekatan dan memperhatikan antara lain : (1) nilai-nilai budaya masyarakat setempat ; (2) struktur sosial masyarakat ; (3) perekonomian masyarakat ; (4) hubungan masyarakat dengan hutan. Berdasarkan hal ini dikoordinasikan dengan instansi terkait, seperti Camat, Kepala Desa dan Dinas Kehutanan Provinsi Jambi

\section{HASIL DAN LUARAN DICAPAI}

\subsection{Peran Serta Masyarakat Dalam Menanggulangi Kebakaran Hutan dan Lahan di Kabupaten Muaro Jambi}

Pelaksanaan penyuluhan hukum tentang kebakaran hutan dan lahan dilaksanakan di kantor Desa Danau lamo kecamatan Maro Sebo kabupaten Muaro Jambi yang dihadiri oleh kepala Desa dan ketua-ketua Rt di Desa Danau Lamo dan desa tetangga serta perangkat desa se kecamatan Maro Sebo. Kehadiran masyarakat kepala desa serta aparaturnya merupakan suatu harapan dari penyuluh dengan dasar, masih ada masyarakat dan aparatur desa yang belum mengerti tentang makna penyuluhan hukum tentang kebakaran hutan dan lahan serta hak dan kewajiban masyarakat terhadap fungsi hutan dan lingkungan. Disamping itu masih adanya masyarakat mudah terpengaruh oleh orang-orang yang tidak bertanggung jawab untuk 
mengambil keuntungan dari hasil hutan khususnya kayu dan lebih ironisnya masyarakat diprovokasi untuk mencari keuntung dari hasil hutan.

Kondisi ini sudah cukup lama berlansung dan sulit diatasi, dan bahkan lebih ironisnya lagi masyarakat ikut terlibat dengan alasan faktor ekonomis. Sementara itu belum efektifnya pengawasan terhadap kebakaran hutan yang dilakukan Dinas Kehutanan Provinsi ikut mempengaruhi terjadinya kebakaran hutan dan lahan. Sebaliknya ketergantungan ekonomi masyarakat dari hasil hutan sulit dihindari, konsekuensinya perladangan berpidah, pencurian kayu akan berpengaruh terhadap kerusakan hutan dan lahan bahkan terjadi pembakaran hutan akibat perladangan berpindah yang dilakukan masyarakat. Berdasarkan hal ini Tim Penyuluh melakukan suatu kajian yang dituangkan dalam bentuk penyuluhan hukum kehutanan dan lingkungan yang dilakukan melalui dua tahap.

Tahap pertama marupakan awal pelaksanakan penyuluhan hukum tentang kebakaran hutan dan lahan oleh Tim Penyuluh yang dilaksanakan melalui survey pada bulan Agustus 2018 dan dihadiri sekitar lebih kurang 30 orang peserta terdiri dari : (1) Kepala Desa dan perangkatnya, (2) Tokoh-tokoh masyarakat, (3) Tokoh lembaga Adat Desa Kecamatan, (5) Kepala Dusun di sekecamatan Maro Sebo. Sedangkan dari apatur pemerintah dihadiri oleh Camat dan Sekwilcam.

Pelaksanaan penyuluhan ini dilakukan melalui diskusi dan tanya jawab yang sebelumnya dipaparkan berbagai permasalahan fungsi hutan dan lahan dalam kerangka mengatasi banjir, erosi dan pembakaran hutan oleh orang-orang yang tidak bertanggung jawab yang akan berakibat terjadinya kabut asap yang sulit ditanggulangi oleh pemerintah. Kemudian dilanjutkan dengan diskusi dan tanya jawab yang berkembang kepada masalah : (1) konflik lahan ; (2) pembabatan hutan ; (3) proses ganti rugi, dan (4) pola kemitraan serta (5) alternatif penyelesaian konflik dan pembentukan Lembaga Arbitrase.

Tahap kedua merupakan pelaksanaan penyuluhan dimulai jam 9.30 wib sampai jam 3.30, untuk peserta disediakan kosumsi dan transportasi oleh Tim penyuluh yang terdiri dari, snek jam 9.30 dan makan siang jam 12.30. Kemudian dilanjutkan kembali jam 1.30 sampai selesai jam 3.30. Teknis pelaksanaannya menggunakan ceramah, tanya jawab kemudian setiap pertanyaan diidentifikasi agar permasalahannya dapat dicarikan solusi yang terbaik. Sebelum tanya jawab berlansung, terlebih dahulu diberikan kesempatan kepada peserta untuk menyampaikan permasalahan yang mareka hadapi dalam meningkatkan peranserta masyarakat dalam pengamanan fungsi hutan dan lingkungan terhadap kebakaran hutan dan lahan.

Dari berbagai permasalahan yang diungkapkan peserta yang disuluh dengan jumlah peserta lebih kurang 50 orang di dua kecamatan, pada intinya adalah berkaitan dengan cara menanggulangi kebakaran hutan. Kebakaran hutan dan lahan dalam cakupan yang luas bisa berdampak buruk pada lingkungan dan juga kesehatan masyarakat. Untuk itu, penting kiranya kita mengetahui cara menjaga kelestarian hutan serta mencegah maupun menanggulangi kebakaran hutan agar bencana tersebut tidak merusak lingkungan. Beberapa cara yang cara yang disampaikan Tim penyuluh agar dapat dilakukan untuk mencegah atau menanggulangi kebakaran hutan antara lain :

1. Memperhatikan wilayah hutan dengan titik api yang cukup tinggi yang dapat memicu terjadinya kebakaran hutan. Wilayah titik api ini harus diperhatikan ketika kemarau panjang terjadi ; 
2. Tidak membuka lahan atau perkebunan dengan cara membakar hutan ;

3. Tidak membuang puntung rokok secara sembarangan di hutan ;

4. Tidak meninggalkan api unggun dalam hutan. Api unggun harus dipadamkan terlebih dahulu jika ingin meninggalkan hutan ;

5. Melakukan patroli hutan secara berkala untuk mengecek kondisi hutan ;

6. Melakukan pemotretan citra secara berkala terutama di wilayah dengan titik api yang tinggi.

7. Menyediakan mobil pemadam kebakaran yang siap untuk digunakan.

8. Apabila terjadi kebakaran hutan berskala kecil, maka lakukan penyemprotan secara langsung ke daerah yang terbakar.

9. Jika kebakaran terjadi dalam skala besar, maka lakukan penyemprotan air dari udara menggunakan helikopter juga membuat hujan buatan.

Sebaliknya issu yang berkembang dalam penyuluhan tersebut adalah konflik lahan dengan beberapa perusahaan perkebunan dan HTI PT WKS, antara lain : (1) Penetapan Kawasan Adat ; (2) Konflik lahan; (3) Konstribusi perusahaan perkebunan dan PT WKS terhadap masyarakat ; (4) Pengakuan Hutan Adat dan (5) Pola kemitraan. Sebelum tanya jawab berlansung terlebih dahulu oleh Tim Penyuluh menguraikan tentang pengertian hutan milik negara, fungsi hutan dan lingkungan dan eksistensi hutan adat berdasarkan Undangundang Nomor 41 Tahun 1999 tentang Kehutanan.

Persoalan yang muncul adalah masalah hutan negara yang statusnya tidak jelas dan akhirnya diambil oleh masyarakat akhirnya muncul masalah kecemburuan sosial. Semantara itu masyarakat membutuhkan lahan untuk perkebunan kelapa sawit dan karet dan lain sebagainya melalui pembakaran hutan dengan dasar menurut masyarakat, hutan negara dapat diwujudkan dalam perkebunan.

Akibat tidak berfungsi peranan masyarakat dalam pengamanan fungsi hutan dan lahan terhadap kebakaran hutan di kecamatan Maro Sebo dan kecamatan Sungai Gelam, kerusakan hutan dan lahan serta lingkungan sulit ditanggulangi dan berimplikasi terhadap berbagai kerusakan hutan lainnya, seperti terjadi kebakaran hutan yang baru-baru ini terjadi. Untuk itu Tim Penyuluh merekomensikan penguatan kelembagaan masyarakat hukum adat dalam mengatasi kerusakan hutan dan lahan serta lingkungan dengan membentuk kelembagaan masyarakat hukum adat yang akan dituangkan dalam peraturan desa melalui pemerintahan kabupaten di kecamatan Maro Sebo kabupaten Muaro Jambi.

\subsection{Penguatan Kelembagaan Masyarakat Adat Dalam Penanggulangan Kebakaran Hutan dan Lahan}

Kebakaran hutan dan lahan di provinsi Jambi terus saja terjadi, peran serta masyarakat lokal harus diperkuat dalam mencegah kasus-kasus kebakaran hutan dan lahan. Model idealnya harus bersifat institusional, artinya pemicu terjadinya kebakaran hutan dan lahan, disebabkan oleh pihak-pihak yang tidak bertanggung jawab akibat faktor manusia yang dalam hal ini adalah : (i) pengolahan lahan perkebunan masih dengan cara dibakar serta (ii) kondisi iklim dan lingkungan sebagai faktor pendukung terjadinya kebakaran.

Kebakaran hutan dan lahan akibat kesengajaan manusia yang disebabkan oleh kelalaian merupakan bencana tahunan yang telah terjadi di Indonesia sejak lama. Berbagai upaya yang telah dilakukan pemerintah nyatanya belum mampu mencegah bencana tersebut 
dan terulang setiap tahun berikutnya. Dalam kaitan ini penyebab kebakaran hutan akibat faktor manusia, antara lain :

1. Pembakaran hutan dan lahan yang tidak terkendali sehingga meluas kelahan hutan merupakan penyebab kebakaran hutan yang terjadi akibat kesengajaan manusia. Pembukaan lahan perkebunan biasanya merupakan latar belakang dilakukannya pembakaran lahan. Dalam skala kecil, kebakaran ini masih bisa diatasi. Sayangnya, jika kebakaran ini merupakann ulah perusahaan besar dan dalam skala besar, akan sangat sulit untuk memadamkan api dalam kebakaran. Kebakaran seperti ini akan sangat berbahaya ketika terjadi di lahan gambut atau rawa ;

2. Konflik antara perusahaan perkebunan dan HTI dengan masyarakat pemilik lahan, perusahaan yang ingin mengambil alih lahan dari masyarakat pemilik lahan biasanya melakukan pembakaran terhadap lahan yang disengketakan. Pembakaran lahan dapat berakibat lahan menjadi terdegradasi sehingga nilai lahan berkurang. Dengan cara tersebut, perusahaan akan lebih mudah merebut lahan dari masyarakat yang memiliki lahan ;

3. Protes oleh penduduk lokal, penduduk lokal yang merasa lahannya direbut juga sering melakukan pembakaran lahan sebagai bentuk protes karena perusahaan perkebunan merebut lahan milik mereka ;

4. Faktor ekonomi masyarakat lokal, masyarakat lokal yang ingin membuka lahan dan hanya memiliki sedikit biaya biasanya melakukan cara instan untuk membuka lahan. Mereka membakar hutan untuk membuka lahan baru. Cara tersebut dianggap lebih mudah dan murah meski akibat yang ditimbulkan sangat berbahaya bagi lingkungan dan kesehatan manusia

5. Tidak efektifnya penegakan hukum terhadap pelaku kebakaran hutan dan lahan. Meskipun aturan mengenai pembakaran hutan jelas-jelas dilarang, namun karena hukum yang diberikan bagi yang melanggar masih sangat lemah, akibatnya banyak juga oknum yang melanggar aturan dan membakar hutan secara besar-besaran untuk membuka lahan. Hal tersebut biasanya dilakukan oleh perusahaan-perusahaan besar.

6. Meninggalkan bekas api unggun atau membuang puntung rokok di hutan. Hal ini biasa terjadi ketika seorang pendaki gunung atau seseorang yang melakukan perjalanan dalam hutan. Api unggun yang dinyalakan biasanya ditinggalkan begitu saja sehingga berpotensi menyebabkan kebakaran.

Berdasarkan ketentuan tersebut di atas, tim penyuluh telah memaparkan kepada masyarakat melalui beberapa tahap. Memalui tahap pertama dan tahap kedua, dapatlah diketahui bahwa peserta yang disuluh terdiri dari : (1) Kepala Desa, (2) Kepala Dusun, (3) Tokoh Masyarakat dan (4) Tokoh Lembaga Adat disetiap Desa di kecamatan Maro Sebo mengatakan, bahwa membuka kawasan hutan lahan dijadikan untuk perkebunan dapat dikelola masyarakat berhubung kawasan hutan tidak ada pemiliknya. Ketentuan ini dikuatkan dengan tambo adat mareka yang mengatakan hutan yang sudah pernah diolah dan ditinggalkan dan tidak meninggalkan tanaman keras (parit nan berkuto) maka hutan tersebut disebut "hutan rimbo gano" artinya dapat dikelola masyarakat disekitar kawasan hutan tersebut.

Persepsi masyarakat tersebut pada hakekatnya ingin menguasai lahan/areal hutan negara untuk diolahnya, akan tetapi tidak mendapat konsensi dari pemerintah dalam bentuk peizinan. Oleh karena itu timbullah berbagai konflik antara masyarakat dengan pemerintah lahan perkebunan termasuk dengan PT WKS sebagai pemegang konsensi penggunaan lahan hutan dan lahan di kabupaten Muaro Jambi. Berdasarkan berbagai pertanyaan masyarakat 
tersebut di atas, maka Tim Penyuluh mencoba mencarikan solusi dengan menggunakan pendekatan : (1) Normatif, (2) Sosiologis dan (3) Historis.

Tujuannya agar masyarakat tidak anarkis dalam menyikapi jawabnya. terhadap semua pertanyaan ditampung, kemudian Tim Penyuluh bersama Camat mengadakan suatu pendekatan terhadap peserta, dengan catatan akan dicarikan suatu solusi yang terbaik antara masyarakat dengan perusahaan perkebunan dan HTI PT WKS antara lain yang berkembang adalah masalah : (i) Kecemburuan Sosial (ii) Pengakuan Hutan Adat ; (iii) Eksistensi Hutan Adat (iv) Masalah Hutan Adat. Sehubungan hal ini tim penyuluh menawarkan penyelesaian konflik merupakan suatu alaternatif dengan musyawarah atau melalui jalur proses peradilan.

Untuk itu Tim Penyuluh mencoba menawarkan penyelesaian konflik dapat ditempuh melalui lembaga mediasi, yaitu penyelesaian konflik melalui musyawarah dengan melibatkan berbagai pihak yang berkepenting terhadap konflik yang timbul. Untuk ini Tim Punyuluh dapat sebagai fasilitator dalam penyelesaian konflik tersebut dengan melibatkan tokoh-tokoh masyarakat, LSM dan pemerintah daerah dengan pihak perusahaan perkebunan.. Model ini dapat dilakukan melalui suatu lembaga independent yang mana putusannya dapat disamakan putusan pengadilan yang bersifat final dan konkrit dan mengikat para pihak dan tidak merugikan para pihak yang dilakukan secara musyawarah di kabupaten Muaro Jambi.

\section{KESIMPULAN DAN SARAN}

Berdasarkan issu yang berkembang dalam penyuluhan tersebut adalah konflik lahan dengan beberapa perusahaan perkebunan dan HTI PT WKS, antara lain : (1) Penetapan Kawasan Adat ; (2) Konflik lahan; (3) Konstribusi perusahaan perkebunan dan PT WKS terhadap masyarakat ; (4) Pengakuan Hutan Adat dan (5) Pola kemitraan. Sebelum tanya jawab berlansung terlebih dahulu oleh Tim Penyuluh menguraikan tentang pengertian hutan milik negara, fungsi hutan dan lingkungan dan eksistensi hutan adat berdasarkan Undangundang Nomor 41 Tahun 1999 tentang Kehutanan.

Akibat tidak berfungsi peranan masyarakat dalam pengamanan fungsi hutan dan lahan terhadap kebakaran hutan di kecamatan Maro Sebo dan kecamatan Sungai Gelam, Tim Penyuluh merekomensikan penguatan kelembagaan masyarakat hukum adat dalam mengatasi kerusakan hutan dan lahan serta lingkungan dengan membentuk kelembagaan masyarakat hukum adat yang akan dituangkan dalam peraturan desa melalui pemerintahan kabupaten di kecamatan Maro Sebo kabupaten Muaro Jambi.

Disarankan kepada pemerintah daerah kabupaten Muaro Jambi untuk mencari model penyelesaian konflik guna menjamin kepastian hukum. Alternatif penyelesaian konflik yang ditawarkan oleh Tim Penyuluh tersebut diterima oleh peserta perlu dipertimbangkan, mengingat kalau proses melalui pengadilan rumit dan kompleks, disamping itu berbelit-belit dan memakan waktu yang panjang. Oleh karena itu disarankan kepada pemerintah segera dibentuk lembaga mediasi dalam mengatasi konflik antara perusahaan perkebunan dengan masyarakat dan Fakultas Hukum Universitas Jambi sebagai fasilitator

\section{DAFTAR PUSTAKA}

Afif Syarif, 1997. Penegakan Hukum Lingkungan di Bidang Kehutanan di Propinsi Jambi, Tesis, Pascasarjana Universitas Padjadjaran Bandung 
Afif Syarif dan Bambang Pamulardi, 2000. Dasar-dasar Hukum Kehutanan, Rajawali Press, Jakarta

Alam Setia Zein, 1995. Hukum Lingkungan ; Kaidah-kaidah Pengeloaan Hutan, Raja Grafindo, Jakarta

Chen, P., J. Miettinen, S.C. Liew, dan L.K. Kwoh. 2008. Sebuah Studi Kasus Pengindraan Jarak Jauh atas Penggunaan Lahan/Perubahan Tutupan Lahan di Lahan Gambut Muaro Jambi, Indonesia, antara 1989 - 2007. Pusat Pencitraan, Pengindraan dan Proses Jarak Jauh, Universitas Nasional Singapura

Kamdya Adysoesanto, 1990. Beberapa Aspek Hukum Kehutanan dan Penerapannya, Tidak Diterbitkan, Jakarta

Mubyarto, et,al, 1994.Laporan Akhir HPH Bina Desa di Propinsi Jambi

Milen, A. 2006. What Do We Know About Capacity Building?, An Overview of Existing Knowledge and Good Practice, World Health Organization. Geneva: De-partement of Health Service Provision.

Wildan Yatim, 1992. Nasib Buruk Hutan Kita dan Usaha Menanggulanginya Dalam Melestarikan Hutan, Yayasan Obor, Jakarta.

Qodriyatun SN. 2018. Kajian Singkat Terhadap Isu-Isu Terkini Kebijakan Penanganan Kebakaran Hutan Dan Lahan. Info Singkat Tentang Kebakaran Hutan, Kompas, Jakarta 